This item was submitted to Loughborough's Research Repository by the author.

Items in Figshare are protected by copyright, with all rights reserved, unless otherwise indicated.

\title{
Rights, citizenship and political struggle
}

PLEASE CITE THE PUBLISHED VERSION

https://doi.org/10.1177/1474885115578052

PUBLISHER

SAGE Publications

VERSION

AM (Accepted Manuscript)

\section{PUBLISHER STATEMENT}

This paper was accepted for publication in the journal European Journal of Political Theory and the definitive published version is available at https://doi.org/10.1177/1474885115578052. Users who receive access to an article through a repository are reminded that the article is protected by copyright and reuse is restricted to non-commercial and no derivative uses. Users may also download and save a local copy of an article accessed in an institutional repository for the user's personal reference.

\section{LICENCE}

In Copyright

\section{REPOSITORY RECORD}

Aitchison, Guy. 2015. "Rights, Citizenship and Political Struggle". Loughborough University. https://hdl.handle.net/2134/15059703.v1. 


\title{
Rights, citizenship and political struggle
}

\author{
Dr. Guy Aitchison \\ g.aitchison@lboro.ac.uk \\ Published: European Journal of Political Theory 2018, Vol. 17(1) \\ DOI: $10.1177 / 1474885115578052$
}

Accepted: August 2014.

This is a pre-publication draft. Please cite published version.

\begin{abstract}
This paper adds a new perspective to recent debates about the political nature of rights through attention to their distinctive role within social movement practices of moral critique and social struggle. The paper proceeds through a critical examination of the Political Constitutionalist theories of rights politics proposed by Jeremy Waldron and Richard Bellamy. While political constitutionalists are correct to argue that rights are 'contestable' and require democratic justification, they construe political activity almost exclusively with reference to voting, parties and parliamentary law-making, neglecting the vital role rights play in political struggle outside and against the official institutions of democratic citizenship. In contrast to the political constitutionalist stress on the patient and reciprocal negotiation of rights within formal electoral processes, this paper locates the political nature of rights in their conflictual logic as 'claims' in multiple spheres that function to mobilise oppositional support against powerful adversaries and challenge dominant understandings. An activist citizenship of rights is frequently necessary, it argues, given the structural barriers of power and inequality that distort legislative decision-making and lead to the denial of fundamental moral entitlements to less powerful groups. The paper provides an illustration of activist citizenship taken from a contemporary squatting movement centred around the right to housing, Take Back the Land. In exercising the moral right to housing, for which they demand political recognition, through the occupation of vacant buildings, the practices of Take Back the Land reflect the conflictual dimension of rights as claims in keeping with their historical role in empowering subordinate groups to challenge unjust relations of power and inequality.
\end{abstract}

There has been a trend in the recent philosophical literature on rights to argue that, in the absence of any authoritative stipulation of our moral entitlements - a stipulation derived from natural law, metaphysical reflection or some foundational moral theory, say - the concept of rights is inescapably 'political'. This political turn in the literature has brought with it a shift in focus from abstract questions to do with the philosophical 
justification of rights to more concrete questions of how they are to be realised in practical circumstances of disagreement. While one important question, to which much of the recent literature is addressed, asks how we should understand those rights known as 'human rights' in light of their role within an international practice aimed at regulating the conduct of states with diverse ethical and cultural traditions, 1 a further debate addresses the implications of pluralism for how rights are achieved and protected domestically. Here, the fact of pluralism provides a starting point for an argument by Political Constitutionalists in support of electoral participation by citizens in the ongoing definition of rights as an alternative to judicial decision-making associated with apolitical modes of justification. Jeremy Waldron and Richard Bellamy provide the most powerful and influential theories of this kind, which they link to a distinctive conception of the nature of rights and the normative relations they entail.2 They argue that rights do not demarcate a domain of morality outside and against politics that functions to limit and constrain it, but instead exist within the 'circumstances of politics' as claims made by equal citizens upon one another regarding the distribution of benefits and burdens within society.3 Since citizens disagree profoundly about rights, they ought to actively participate in how they are decided through the election of representatives to parliaments with sovereign authority over the content and distribution of rights and their weight in relation to other political concerns. Political constitutionalists have mounted a number of powerful arguments against judicial review of rights on both normative and pragmatic grounds. I do not intend to rehearse these arguments here, but instead explore the implications for thinking about the nature of rights and the forms of politics necessary and appropriate to their realisation once we agree that citizens have an active role to play in their ongoing definition and enforcement. I argue that the political constitutionalist account of rights-based citizenship misleads in important respects since it construes political activity almost exclusively with reference to voting, parties and parliamentary law-making, neglecting the vital role rights play as a vocabulary of protest in practices of moral critique and social struggle outside and against the official institutions of democratic citizenship. The aim is not to refute the argument of Waldron and Bellamy that rights are 'contestable' and require democratic justification, but to broaden our understanding of the nature and dynamics of political 
contestation beyond the institutional and temporal boundaries of elections and parliamentary law-making. I argue that a commitment to the democratic justification of rights entails recognition of the importance and legitimacy of an array of contestatory activist practices that both render political decision-making more equal and inclusive and serve as an important source of moral innovation. When debate over the realisation of rights is framed as a choice between juridical and parliamentary modes of citizenship, little consideration is given to the significance of social movement activism as an independent domain of creative political action. This is a notable oversight. In cases where neither parliament nor judges could be relied upon, rights have been achieved and defended through the exercise of direct popular power in pursuit of the emancipation of women, workers, racial minorities and other subordinate groups even in cases where those groups enjoyed formal rights of political participation. 4 This fact lends social movement practices of critique, protest, disobedience, direct action and other modes of contestation, at least prima facie importance to an understanding of rights. Democratic theorists have noted the need for political actors to engage in activist politics of this kind, which may take disruptive and coercive forms, in situations where structural inequalities and failures of reciprocity privilege the dominant interests of political and economic elites or majority social groups.5 Historically, this form of conflictual claim-making has been especially important in situations in which moral rights are denied since, as I go onto show, those situations are generally characterised by sharply conflicting interests in which formal processes of political persuasion, compromise and negotiation have broken down.

The central argument of the paper is that the theories of rights-based constitutional citizenship proposed by Waldron and Bellamy should be supplemented by a theory of activist citizenship that accounts for the vital role of social movements in supporting democratic participation and moral innovation. Crucially, recognition of the importance of activist citizenship entails more than a straightforward empirical point about the historical contribution of social movements to the realisation of rights in democratic societies: it bears on our understanding of the nature of the concept and the role it plays in our politics. In part I of this paper, I show how the political constitutionalist stress on 
the patient and reciprocal negotiation of rights within formal electoral processes overlooks their distinctive conflictual role as 'claims' in multiple spheres that function to mobilise oppositional support against powerful adversaries and challenge dominant political understandings. In part II, I argue that a preoccupation with the undemocratic powers of courts leads political constitutionalists to overlook the deep-seated problems with legislative decisionmaking and the more serious structural barriers of power and inequality that necessitate an activist citizenship of rights. In part III, I provide an illustration of activist citizenship taken from a contemporary squatting movement centred around the right to housing, Take Back the Land. In exercising the moral right to housing, for which they demand political recognition, through the occupation of buildings left vacant by banks and local government, the practices of Take Back the Land reflect the conflictual dimension of rights as 'claims' in keeping with their historical role in empowering subordinate groups to challenge unjust relations of power and inequality.

\section{Conflictual claim-making in the politics of rights}

The political constitutionalist commitment to parliamentary decision-making stems from a particular account of the conceptual nature of rights as democratic claims addressed to others within a shared political community. In an analysis of the basic structure of a right, Bellamy aims to show how certain logical and normative features of rights make it particularly appropriate that their content, weight and distribution be decided by a democratic procedure in which all those affected can take part. 6 The case for democratic decision-making, as he puts it, stems from 'the very nature of rights and the claims we make of others with regard to them'.7 It is important, for Bellamy, that rights be asserted in a 'democratic spirit' due to their logical form and content which entails that the recognition of any right has implications for others within a shared set of collective arrangements. 8 The argument that democracy follows conceptually from the nature of rights is presented, by Bellamy, as a challenge to a particular 'liberal' reading of rights he associates with Ronald Dworkin, which conceives of rights as 'trumps' that protect a prepolitical sphere of freedom from potentially myopic and 
tyrannous democratic majorities.9 The liberal impulse to divorce rights from democratic decisionmaking is a function of a reductive misconception of the normative relations they entail. As Bellamy puts it:

Rights are sometimes presented as a two-term relation, whereby $\mathrm{x}$ has a right to some y. That gives rights a somewhat peremptory sounding character. However, rights are always a three term relation, whereby $\mathrm{x}$ asks some $\mathrm{z}$ to recognize and respect his or her claim to $\mathrm{y}$, with attendant costs and benefits to $\mathrm{z}$ who will wish $\mathrm{x}$ to like- wise recognize either his or her similar claim to $\mathrm{y}$, or to some other good such as v.10

This political conception brings into the picture the complex web of relationships in which a right is embedded in a valuable corrective to atomistic liberal theories, which retain the fiction of the early modern social contract tradition that rights protect the prepolitical liberty of isolated individuals. In his emphasis on the reciprocal, co-operative qualities of rights, Bellamy addresses the long-standing criticisms of conservatives and radicals that condemn the discourse of rights for its anti-social egotism. 11 The emphasis on the patient negotiation of rights, which we 'ask' others to recognise and respect, arises out of a legitimate concern with the misleading simplicity of a litigious culture of individualistic 'rights talk' in which entitlements are asserted in a selfish and dogmatic manner indifferent to the burdens placed on others.12 The problem lies in the idealised picture of a rights claim, which, in assuming communicative parity and an egalitarian framework of shared values, jettisons what is valuable about the concept in empowering agents to contest unjust relations of power. There is an under-explored tension in Bellamy's account between the reciprocal negotiation of rights in a 'democratic spirit' and what he describes as their 'traditional' role as claims that can hold power to account.13 This idea of claiming brings to mind a purposeful, self-assertive form of politics that Bellamy's conception appears to have little room for.

Waldron's writings also tend to overlook the central importance of conflictual claiming to the politics of rights, reducing rights to ordinary forms of reasongiving. Waldron 
works with a conception of rights as weighty political reasons, which follows from his endorsement of Joseph Raz's interest theory view in which a right stands in a relationship of normative justification to a duty, rather than a relationship of logical correlativity.14 According to Raz, 'one may know of the existence of a right and the reasons for it without knowing who is bound by duties based on it or what precisely are these duties'.15 This view has been criticized for losing the distinctive significance of rights in normative reasoning, which is based on the directional nature of the duty being owed to the claim-right holder.16 As I go onto show, this directional quality is crucial to understanding the political nature of rights in empowering individuals to make demands upon specific others. In the absence of this relationship of accountability, it is difficult to distinguish adequately between rights and other reasons for action, such as needs and interests. Waldron frequently portrays disagreements about rights as the polite exchange of reasons. He claims that disputes about rights among professional philosophers are as 'fundamental' as those that divide citizens, 'and yet we maintain not only civility with one another, but a quite robust professional esprit de corps and even friendship with those we oppose'.17 Having said he is interested in the circumstances of politics, this is a peculiarly unrealistic comparison for Waldron to make. The social interests of philosophers are not fundamentally at stake in the polite and reasoned disputes of academic conferences and there is an openness to these exchanges that distinguishes them from the communicative asymmetries characteristic of the real-world situations in which rights are claimed.

It is worth reflecting on why the notion of rights is closely linked to that of claims in philosophy and common usage in order to arrive at a more robust and realistic account of the place of rights in political argument. The significance of rights being 'claims' was famously recounted by Joel Feinberg. Although Feinberg's writings are known for a number of important distinctions, his recommendation that we understand rights not according to some overarching 'formal' analysis, but in light of the 'activity of claiming, which is public, familiar, and open to our observation' has been left underexplored.18 This approach nonetheless provides a fruitful pathway for exploring the political characteristics of rights since it orientates us to the active, verbal form of the 
term 'claim' (in contrast to its more passive, possessive form) and the dynamic social processes of conflict and disagreement in which rights are asserted and acted upon by their bearers. Feinberg's analysis draws on contemporary developments in linguistic philosophy and the analysis of 'speech acts' by J.L. Austin and others who took from Wittgenstein's linguistic pragmatics the idea that 'words are also deeds' with a function of doing certain things in language 'games'.19 As Feinberg puts it, rights are things we can stand on, activate and deploy in social situations when required, 'not mere abstract concepts'; but 'instruments and devices that can be used by their possessors to do things'.20

Feinberg's focus is on 'claim-rights', which are rights in the 'strictest sense' according to Hohfeld's influential categorisation.21 Significantly, Hohfeld's analysis notes that a claim correlates to a duty owed to the claim-right holder and that it is held against the bearer of the correlative duty.22 While Hohfeld was concerned with the logical structure of a claim-right, Feinberg addresses their distinctive normative function. He proposes a flexible definition of moral rights as 'valid claims', which consists of a claim 'to' some good 'against' someone that is justified through an appeal to 'moral principles, the principles of an enlightened conscience'.23 The significance of rights having this structure is brought into focus through the famous account of the hypothetical world of Nowheresville in which subjects are owed obligations, but lack the corresponding rights to enforce them, which are in the hands of a 'sovereign rights monopoly'. The subjects of Nowheresville may benefit from the performance of obligations by their fellow subjects, and the failure to perform these obligations is a wrong. But since the obligations are not owed to them personally, they lack the normative authorisation for a specific set of demanding attitudes and responses associated with a dignified moral standing.24 A world without rights suffers a serious loss, Feinberg says, since:

In appropriate circumstances rights can be asserted authoritatively, confidently, and unabashedly. They are not gifts or favors; motivated by love or pity, for which gratitude is the sole fitting response. A right is something a man can stand 
on, something that can be demanded or insisted upon without embarrassment or shame. When that to which one has a right is not forthcoming, the appropriate reaction is indignation; when it is duly given there is no reason for gratitude, since it is simply one's own or one's due that one received. 25

Whereas the remedial responses connected to the possession of a right are usually thought of in terms of legal powers to enforce them in courts and seek compensation in the event of non-fulfilment, here the exercise of rights is understood in terms of moral powers of admonition. Rights are something we can 'stand upon' and this standing is associated with psychological traits of self-esteem and a more confident and assertive attitude in contrast to the degrading and servile dispositions that come with being at the mercy of another's good will

It is part of the proleptic quality of the discourse of moral rights that it has a certain immediacy and authority to its usage: those denied their rights may urge their recognition in the here and now; furthermore, as a personal wrong, done to them, because the duty is owed to them, and it is particularly appropriate therefore that they protest about it.26 It is notable how the first step subordinate persons, such as racial minorities and exploited workers, take towards the achievement of rights is the understanding of themselves not as a powerless figures, as suggested by dominant narratives designed to devalue their identity and make them feel helpless, but as agents worthy of respect entitled to hold others accountable for their treatment.27 Whereas political constitutionalists tend to associate the notion of respect with the actual possession of formal voting rights, 28 this account affords an alternative perspective on how the wider practice of moral rights may constitute individuals as 'makers of claims' with self-respect to demand proper treatment even in the absence of institutional channels of redress. This helps make sense of how the vocabulary of rights empowers agents with little formal political leverage to protest their condition against powerful institutions and social groups. The conflictual dynamic at work here stems from the fact that the addressee of a right - agent ' $z$ ' in Bellamy's 
picture - is not only an obligation holder, but more often than not a rights withholder who has most to lose from the recognition of x's right to $y$. They may be a boss denying her workers a livable wage; a racial minority that enjoys economic and political privileges at the expense of a majority; an authoritarian government restricting freedom of protest, and so on. It does not follow that rights must always be insistently demanded. Recall the distinction between the possessive and verbal forms of 'claim': one may hold or exercise one's claims without ever having to 'claim' them in the stronger, verbal sense. In routine cases, where we are sure of our entitlements, and there is little threat of violation, we may exercise them quietly, as with the regular churchgoer who has little need to dwell on or defend the freedom of religion they enjoy. It is not a necessary condition for the possession of a right that it be claimed by its bearer. The self-directed, assertive forms of conduct we associate with claiming may however be a necessary condition for the operation of the practice of rights as a whole. If rights never had to be claimed, the concept would likely fall into disuse since it would be sufficient to offer ordinary reasons for action to other agents in terms of an objective expression of interests, in the form of 'wants' or 'desires', without the need to invoke the distinctive interpersonal authority of rights.29 This explains why the canonical rights, such as property, freedom of speech and religion, denote areas of individual freedom where there has been a historical pattern of interference and social conflict, while those freedoms not historically threatened by self-interested interference, such as how many hours we sleep each night, are not typically thought of in terms of rights.

Naturally, these conflicts of interests do not rule out the formal processes of reciprocal negotiation and persuasion political constitutionalists envisage. It may well be, for example, that someone who is a $\mathrm{z}$ in one situation will be an $\mathrm{x}$ in another situation and so nonetheless have their interests advanced overall, as with the healthy taxpayer who happily pays towards a universal right to healthcare he takes advantage of at some later date when he falls sick. It is part of the egalitarian character of rights that they will often have this reciprocal quality. Yet reciprocity is not an essential feature of rights. It does not hold where there is no possibility of z's becoming x's (as with rights against racial and gender discrimination, say) and while it holds for some rights when we consider 
the practice of claiming over a long enough time period, it does not detract from the fact there is a genuine conflict of interests at the moment the right is claimed. Moral rights tend to enter the foreground of our consciousness when denied and it is in precisely these circumstances that their value becomes apparent. As Robert A. Williams, Jr. put it:

One cannot experience the pervasive, devastating reality of a 'right', however, except in its absence. One must first be denied that seat on the bus, one must see the desecration of one's tribe's sacred lands, one must be without sanitary facilities in a farm field, to understand that a 'right' can be more than a concept. A right can also be a real, tangible experience. 30

It may be that the invocation of a right succeeds in persuading the addressee to change their behaviour, but this can hardly be relied upon given the likelihood of conflicting interests. This explains why the justification of rights invokes rules and principles that appeal to third parties - some agent ' $\mathrm{w}$ ' - to intervene on $\mathrm{x}$ 's behalf against z.31 With legal rights claimed in court, the appeal is to legal reasons and the third party is the judge, who is in a position of authority, according to institutional rules, to oversee the relationship between $\mathrm{x}$ and $\mathrm{z}$. In politics, the appeal is to moral principles, the "principles of an enlightened conscience', but the identity of the third party is less determinate. For political constitutionalists, the third party is implicitly understood as voters or legislators with indirect institutional authority through their input into parliamentary law-making. But once we conceptualise the activity of claiming beyond elections and parliaments, the third party may be citizen activists, campaign groups, political parties or in certain cases of severe deprivations, other states and international institutions, while the forms of political intervention available with which to support the rights claimant include not only voting, but an array of protest-related activities, such as petitions, strikes, sit-ins, marches, meetings, boycotts, vigils and so on.32

Of course, claiming a right is not equivalent to 'having' one: the mere fact an agent claims a right does not entail that it is a morally justified 'valid claim'. It may be that 
the claim lacks a sound moral justification and is therefore not recognised by relevant third parties who can secure its authoritative enforcement. Alternatively, the right may have a sound moral justification, but be ignored or opposed by those with the political power to enforce it because it threatens their interests. Immediate recognition is not the only measure of success for a rights claim however. A morally justified claim that is not recognised as 'valid' by third parties with the political power to enforce it will have still achieved partial success if it is persuades at least some others to recognise it and intervene on behalf of the claimant. It is often the case that demands for moral rights initially ridiculed or ignored come to be seen as part of the general 'common sense' thanks to ongoing practices of critique and activism that build political support over time.33 This offers a fresh perspective on Marx's famous dictum that 'between equal rights, force decides'.34 The realist perspective associated with this prognosis provides a worthwhile check on the abstract moralism of utopian theories of rights that pay little attention to the relations of power that block the achievement of those very rights for subordinate groups. Yet what the juxtaposition between impotent 'rights' and strategic 'force' misses is the way in which the political articulation of a right may itself be a form of power; a form of communicative power that can galvanise third parties into oppositional political action. In the next section, I examine how an orientation to the conflictual dimension of rights politics informs our understanding of how rights are defended and expanded in circumstances of asymmetrical power.

\section{Rights, disagreement and ideology}

The central insight justifying parliamentary decision-making, for political constitutionalists, is the contestable nature of rights, which, far from being natural or self-evident, are subject to deep and widespread disagreement. We disagree profoundly about what rights we have, why we have them, who has them and the weight they should be accorded in relation to one another and to other political concerns. As Bellamy and Waldron point out, these disagreements are intimately linked to the ideological divisions that characterise any modern, pluralistic political community. Given the absence of any epistemological criteria to adjudicate between competing conceptions 
of rights, there is a need for a democratic procedure to resolve our disputes and reach a decision.35 As will become clear, I do not wish to deny or evade the ultimate need for such a decision. In the final instance, there is a need for a collective decision-making process on rights that is legitimate and authoritative. However, even under favourable conditions, the formal procedures of participation through which collective decisionmaking is institutionalised are far from being exhaustive of politics and by themselves will not give voice to the diversity of democratic opinion on rights in the absence of activist practices of citizenship to hold political institutions inclusive and accountable.

Part of the attraction of democratic majoritarianism highlighted by Waldron and Bellamy is that it can provide a check on the rights of wealthy and powerful minorities by opening the official regime of rights to ongoing democratic revision and contestation.36 This is an important aspiration given the tendency of economic elites to defend their privileges by freezing a particular conception of rights, based on individualistic 'negative' liberty and private property, beyond the reach of collective decision-making in the hands of judicial guardians.37 This is only part of the story however since elites defend their interests not only through constitutional entrenchment, but through the ordinary legislative process. The political constitutionalist account focuses on a single dimension of power in the form of legislative decision-making, implicitly assuming a smooth translation between citizens' undistorted preferences with respect to rights and the votes of their representatives. Their approach overlooks less visible and more insidious dimensions of power, which allow social and economic elites to shape the decision-making agenda of the legislature through such means as lobbying, party finance and campaign groups, while indirectly manipulating public discourse and the preferences of voters through control over the media, education and cultural and social institutions.38 It is precisely these subtle and more pervasive power relations critical theorists call attention to when they argue that today's dominant discourse of liberal rights masks an inherent ideological bias towards the capitalist free market and the interests of private property. 39 Here, the threat to rights is not so much the tyranny of the majority, but the tyranny of the minority: the domination of non-mobilised citizens by elites acting in their own interests. In such cases, decisions about rights that 
threaten powerful groups may in fact be 'non-decisions', kept off the political agenda altogether. 40

Bellamy's theory of 'constitutive citizenship', with its orientation to electoral processes of alliance building in civil society, addresses the dangers of private concentrations of power in a way that Waldron's focus on parliamentary debate does not. Bellamy draws on interest-group pluralist models of decision-making, according to which legislative majorities are shifting coalitions of minorities, which entails that no minorities are permanently ignored.41 For Bellamy, under a competitive party system, with 'one person, one vote', which requires voters to 'hear the other side', if a citizen fails to have their rights claim recognised it is due to

not convincing fellow citizens that their view would treat all with equal concern and respect and that comes from not heeding their equally important rights claims of a sufficient number of their fellow citizens so costs and benefits fairly shared by all.42

The explanatory relevance of the pluralist model of power this account draws on has not gone uncontested, with one of the most influential pluralist theorists, Robert Dahl, coming to revise his earlier assessment in the context of the vast inequalities of wealth and power in US politics.43 There is now a growing body of empirical literature that challenges fundamental pluralist assumptions as they relate to contemporary liberal democracies. Jeffrey Winters, for example, has recently characterised the US political system as an 'oligarchy', pointing out that, regardless of formal political equality, 'yawning differences in material power create enormous inequalities in political influence and account for key political outcomes won by oligarchy'. Contrary to pluralist views, there is no countervailing influence to this force. Thus, the "expression of minority power operates within a liberal democratic framework, but almost entirely off the national radar screen and through means that cannot be understood by representation, voting, or pluralistic politics'.44 In the UK, structural changes in the domestic and global economy have had a similar hollowing-out effect on democratic 
institutions with a lack of countervailing forces in the public sphere to subordinate the interests of economic elites to collective law-making. 45

This more comprehensive picture of power relations proves problematic for political constitutionalism, which tends to construe conflicts about rights as a species of reasonable moral disagreement. Bellamy draws on the deliberative strain in Rawls's theory in Political Liberalism, extending the 'burdens of judgment', which express the limits of human reason, not only to conceptions of the 'good' but to conceptions of the 'right'.46 Similarly, Waldron notes how Rawls's burdens of judgment apply to 'the public issues of justice and right that are under discussion in politics' 47 Undoubtedly, the considerations of the burdens of judgment matter in controversies over rights, but it is a mistake to think that they are in some sense neutral and not shaped by the relations of power and interest that structure people's perceptions of political reality. An emphasis on the complexity of political decision-making, due to the deficiencies in our knowledge, often has conservative implications. As Sheldon Wolin puts it, in a critique of Rawlsian political liberalism, the 'rhetoric of the desperate is likely to be a simplifying one, reflective of a condition reduced to essentials', while a 'rhetoric of complexity, ever since Burke, has found favour with those whose expectations are secure'.48

Even under favourable conditions that presume political institutions are responsive to a majority that is well motivated and acting in good faith, there is the likelihood that a majority will not 'see' the injustice of a particular issue facing minorities unless challenged to do so through political actions that disrupt routine patterns of thought and behaviour and present alternative moral and political principles.49 As John Medearis points out, 'acting, as they do, in societies characterized by significant inequalities of power' social movement face systematic barriers to democratic inclusion for themselves and their arguments' and 'must often act coercively in order to achieve democratic aims'.50 The inequalities of power, wealth and status that make rights necessary also create dramatically unequal bargaining positions when it comes to the mobilisation of political resources and influence: those struggling to have their rights 
recognised are often from marginalised, exploited groups without access to the levers of power. In the next section, I develop an activist account of rights politics attentive to these political realities.

\section{Rights politics beyond parliament}

It is striking how, in the various writings by political constitutionalists on the subject of rights, disagreement and law, there is little attention to the question of what a citizen who disagrees with the law on the basis of rights and can't influence the ordinary political process should do. The political constitutionalist account is near silent on forms of political action outside formal channels of participation. Although the struggles of women and workers to gain the vote are celebrated, it is their destination that is important - the fact that, they 'did these things to secure a voice on the matters of political principle that confronted their community' - rather than the political means they used to get there and the role of rights as a vocabulary of protest within these struggles.51 In their determination to protect the integrity of laws by parliament from the counter-majoritarian difficulty of judicial review, they fail to appreciate the role of rights as asserted outside and against the law through an appeal to fundamental moral norms claimed to override parliamentary law-making

Waldron's Law and Disagreement contains only one (disapproving) reference to civil disobedience. He discusses the Clay Cross councillors in Britain in the 1970s who refused to implement the Tory government's raising of public housing rents and the subsequent Labour government's legislation removing all penalties from the councillors for their stance as an example of 'not enough respect for the law'.52 There is a notable tendency in Waldron's work to focus on constitutions, parliaments and courts, as though these constituted the entire domain of politics. 53 Bellamy devotes more attention to the role of social movements, yet their political significance is principally understood as a constituency of defined policy interests that can leverage influence by bargaining with other interest groups to form electoral coalitions.54 The ballot has undoubtedly been an important means by which social movements have achieved their rights, but 
the significance of activist citizenship cannot be reduced to this instrumental electoral role. Political change that is significant and lasting typically requires a transformation of the norms and values of political society as a whole, which is why social movements nearly always have an 'expressive' dimension to their activities.

aimed at reconfiguring dominant cultural and social assumptions. 55 Furthermore, there are groups in society who lack formal voting rights or whose vulnerable and stigmatised status mean they lack the means to exercise them effectively.56 Bellamy's model cannot account for how excluded groups challenge the makeup of the polity from outside its boundaries. Bellamy argues that rights to the democratic process were won 'within existing, normal democratic politics'.57 In reality, the legislation of equal votes for women and workers was the culmination of a long and bitter historical struggle outside parliament involving practices of citizenship outside official channels. Excluded social groups and classes did not overcome barriers to citizenship through the exercise of the very political powers they were struggling to attain.

There is, then, a need for activist forms of citizenship to supplement, and even substitute for, constitutional citizenship where the formal channels of political participation are unavailable or unreliable. In this model, rights claimants are not conceived just as equal citizens within ordered processes of electoral negotiation and persuasion, but also as self-assertive individuals purposefully demanding recognition of what they take to be their rights by exercising them directly regardless of their official recognition through appeal to fundamental moral principles that are thought to override democratic lawmaking. An example of activist citizenship in relation to the right to housing will serve as an illustration. Despite its authoritative expression in the Universal Declaration of Human Rights and other international human rights documents, the right to housing remains deeply controversial due to its status as a 'positive' right that entails obligations of provision, potentially placing heavy burdens of taxation on the state in a way that conflicts with the dominant free market ideology of private property and reduced welfare provision.58 In response to these controversies, philosophers have offered justifications for the fundamental importance of decent accommodation to human well- 
being and the effective enjoyment of other rights, accompanied by sophisticated accounts of how the corresponding obligations are to be allocated and fulfilled.59 Although my discussion bears on these questions, my aim here is not to add support to what I take to be an already persuasive philosophical case for a right to housing, but rather to demonstrate how the nature and logic of the political practices through which the right is contested and given content embody the features of an activist citizenship of rights.

With the recent economic crisis and subsequent increase in homelessness, housing has become a major issue of political contention with squatting, eviction resistance and rent strikes - practices traditionally associated with land struggles in the global south - once again emerging as central elements in the political repertoire of rights claimants in wealthier economies. In Europe and the US, squatting has been adopted as a political strategy by elements within the 'Occupy' movement of public square encampments that emerged from 2011 to protest economic injustice.60 These movements explicitly frame their activities as a form of political action in pursuit of housing as a human right. One group engaging in such tactics, in the US, where the housing crisis is particularly acute, is Take Back the Land, which started in 2006.61 Max Rameau, one of the originators of the campaign, states their claim in the following terms:

I think what's happening is we're having a real clash between two rights, or at least perceived rights. One is the right of human beings to have housing, and the other is the right of corporations to make a profit. And there's a clash going on between these two rights, or perceived rights, and the society is starting to work out which one it thinks is the most important right. And we are asserting that the right of human beings to housing supersedes the right of corporations to make a profit. And I think people are starting to come to that same conclusion.

The claim of Take Back the Land is articulated on behalf of a collective 'we' that consists of the poor and dispossessed class of homeless. Their claim is a distinctively political one that reflects an underlying appreciation of the social implications of a right 
to housing in terms of the benefits it confers on a whole class of materially deprived persons and the obligations it places on banks and corporations, who are singled out (alongside state authorities) due to their vast wealth and their role in the sub-prime mortgage crisis. This contrasts with individualistic modes of claimmaking political constitutionalists problematise in legal avenues of redress, in which entitlements may be asserted with little thought for who has the corresponding obligations and how they are to be delivered.63

Furthermore, the right to housing is asserted by Take Back the Land in an adversarial manner. Avenues of reasonable negotiation and persuasion with the banks have been tried and failed: they have ignored requests for mitigation in mortgage repayments and now seek to evict people from homes that are then kept vacant. The group therefore takes the view that families without homes ought to be housed in these empty properties in open defiance of the banks' legal property rights. There is a clear coercive edge to these activities. The right to housing is not simply being offered up as a proposal in the course of discussion, but acted upon and defiantly asserted as a vivid manifestation of the ethical conflict between two rights. As with other political movements of squatters, part of the aim of the group is to achieve a critical mass of occupied houses to overwhelm the system and force a response from the authorities. 64 The formal channels of electoral participation cannot be relied upon, under Rameau's view, since the 'job of local government is not to serve the interests of regular people, much less poor black women', but to 'serve the interests of big business, such as wealthy developers'. 65 Their political power and leverage comes not from electoral negotiation, in the manner of constitutional citizenship, but from their physical occupation of housing and land.66

It is important to the ethos of Take Back the Land that it is led by those who suffer from homelessness, especially poor, black women. As 'makers of claims', they speak for themselves in a way that challenges the de facto exclusions of class, race and gender they associate with official forms of citizenship. In eschewing formal representation, the group acts on the prefigurative politics of 'as if', meeting their material need for land and housing directly. Their interpretation of the right to housing is thus manifest 
in the alternative worlds they temporarily create through their occupations. In common with other squatting communities, Take Back the Land actively take charge of the vacant property, assuming responsibility for the upkeep and maintenance of the community and participating in its management democratically in accordance with ideals of 'dweller's control'.67 This is a transformative understanding of the content of rights not contained within the US constitution (which has no mention of social rights) and the established discourse of the political parties. Although the group does not reject provision of housing by the state given their pressing material needs, their claim ultimately calls not simply for top-down provision but for the decommodification of housing, which is to be put under collective ownership in line with a social conception of property based on social need and not individual profit. Along with an interpretation of the right's content, occupation also functions as a demonstration of the moral weight the group accords the right through their willingness to place themselves in harm's way, facing possible violence, arrest and prison time. As noted, the proleptic language of moral rights, with its immediacy and authority, lends itself to this form of claimmaking: the homeless cannot wait upon the cycle of elections and constitutional decision-making given the urgency of their condition.

Typically, such confrontational forms of activism often raise concerns that disruption risks undermining the authority and effectiveness of democratic decisionmaking in a way that risks widespread disorder. The most influential liberal accounts of civil disobedience address these concerns within a justificatory framework that conceptualises principled law-breaking primarily as a (suitably constrained) corrective device. Under this picture, the purpose of oppositional activism is to remind wayward political majorities of the principles of justice they are already nominally committed to in a manner structurally parallel to the institution of judicial review of constitutional rights.68 It should be clear from the discussion thus far that the role I envisage for activist citizenship is importantly different. The justification of activist citizenship lies not in its capacity to restore an agreed account of justice, but in the way it renders political decision-making more equal and inclusive and thus opens society's understandings of justice to ongoing revision and contestation. 
Some measure of protest and disruption are frequently the only means available to the politically powerless, as the case of housing clearly illustrates. Perhaps more than any other group, the homeless are susceptible to having their political grievances ignored. Not only is a place of residence where one is officially registered usually a prerequisite for the exercise of formal citizenship rights through voting, but the social stigma attached to the homeless, along with the instability of their situation, renders effective political participation almost impossible.69 Those of us who live in large urban areas where poverty is widespread are generally conditioned by socially engrained patterns of thought and behaviour not to 'see' the homeless or 'hear' their pleas for help. 70 The dominant public discourse around homelessness encourages us to think of it not as a social injustice, but as a matter of personal responsibility and moral failing. 71 If we do consider the homeless politically, it is generally not in terms of their own political agency, but as an abstract statistic and social problem.72 The practice of organised groups of homeless actively housing themselves (making claims), rather than waiting to be housed (possessing claims) represents a decisive challenge to these ideas, casting the homeless as political subjects rather than passive recipients of aid.

I have refrained from elaborating a precise set of conditions under which such adversarial practices are morally or strategically justified, which lies beyond the scope of this paper.73 The foregoing discussion nonetheless suggests that a complex set of considerations are likely to be involved based on the moral urgency of the claim, the political power and resources available to the claimants, the responsiveness of formal political institutions to their interests and the extent to which the claim threatens dominant groups and unsettles entrenched assumptions. It follows that not everyone has licence to go around aggressively demanding rights in any circumstances. Furthermore, it seems reasonable to suggest that the means of political action chosen should be proportionate to the aims, so that while the physical occupation of vacant homes may be justified, their wanton destruction would almost certainly not be. Acceptance of the demand for democratic justification is another important factor. Although there is a clear adversarial logic to the group's activities, they nonetheless justify their claim with 
reference to moral principles, such as 'dignity' and 'freedom' underlying the practice of moral rights as a whole. This appeal to a criterion of normative validity ostensibly shared with the banks and state authorities calls on these addressees in the first instance to change their behaviour voluntarily and thus displays a degree of respect that marks the claim as distinct from insurrectionary acts of violence or theft. Nonetheless, given the anticipated opposition of these institutions, the claim also functions as an appeal to 'society', which, in the words of Rameau, is beginning to 'work out' its position on the right to housing. The state, under this picture, is not a neutral terrain for the resolution of disagreements about rights, but one (though arguably the most important) third party who may either take the role of adversary in evicting occupants on behalf of the banks or the role of ally in either refusing to evict them or providing alternative accommodation.

In marked contrast to the political constitutionalist emphasis on even-handedly 'hearing the other side', Take Back the Land's claim is presented as a morally clearcut one based on the affront to human 'dignity' inflicted on the homeless due to the 'greed' of a wealthy few.74 This stark polarisation of the issues does not preclude a later more balanced consideration of the complex, far-reaching implications recognition of the claimed right to housing would entail, involving the role of private finance in mortgage lending and construction, the nature and limits of private property rights, the distribution of land ownership, the racial and class politics of gentrification, and so on. Rather, such 'shock tactics' are seen as a necessary precondition for the consideration of these more fundamental systemic issues within official public discourse.75 Although this moral forcefulness gives the claim an absolutist-sounding quality, the democratic appeal to moral arguments intended to convince fellow citizens distinguishes it from the unilateral assertion of a moral truth, which political constitutionalists problematise in the idea of 'trumps' that override majority opinion in the manner of a judicial ruling.

The accompanying rhetoric of the ' $99 \%$ ' versus the ' $1 \%$ ' explicitly places the claimants on the side of the majority and understands the threat to rights in terms of the selfinterested rule of an oligarchic elite.76 Naturally, third parties may find the 
justifications unconvincing and ignore the call for support. In the most extreme scenario, they may even intervene against the occupiers, perhaps by public denunciation of squatting in the media or the organisation of a counter protest in support of consumer rights of access to an unregulated housing market. The moment of constitutional decision marks only a temporary closure in this open-ended politics of disputation. Activist citizenship is thus part of an ongoing process of contestation through which citizens exercise their capacities for judgment and political action beyond the institutional and temporal boundaries of the official channels of political participation.

\section{Conclusion}

The foregoing examination of an activist politics of rights points to a different way of construing their political role; one which accounts for the practices of adversarial critique and struggle that have been a central means by which hierarchical social orders have been challenged and reconfigured since the origins of modern rights discourse. It is clear from the writings of Waldron and Bellamy that the emphasis they place on political participation is based not only on a normative concern with democratic legitimacy, but a political concern that an elitist regime of judicially enforced negative rights will entrench inegalitarian regimes of private property and the related concern that such a regime favours those already privileged groups who can afford the costs of litigation to defend their private interests. These are important concerns. Yet we must also be wary of construing rights politics in such a way that overlooks their rebellious deployment through practices of critical opposition in multiple spheres. A theory of rights-based citizenship based on political equality and open to the transformative claiming of rights cannot afford to ignore the importance of activist citizenship. Once we accept the political constitutionalist insight that rights are contestable and that plurality, dissent and disagreement are integral to their creation, definition and enforcement, our understanding of principled political contestation should be broadened beyond voting and parliamentary law-making. As I have shown, the role of rights in politics is not simply as a weighty electoral interests traded among legislators and voters, but as claims that interrupt the ordinary flow of debate and empower 
marginalised groups to enter the political arena and force new critical perspectives into public discourse. They may not automatically win the political game in the manner of a trump in a game of cards, but the assertion of a justified moral right may nonetheless appeal to norms that override democratic law-making and require extraordinary political intervention to overcome unresponsive political structures or else to compel majorities to confront their own assumptions and prejudices. As this article has argued, rights have important conceptual characteristics that support this conflictual role, which explains why they have proven such a useful tool for social movements challenging unjust relations of power and inequality since their earliest origins.

\author{
Notes \\ 1. The literature on international human rights is oriented to a distinct set of political \\ concerns, primarily in relation to the limits of state sovereignty and responses to \\ global poverty. See John Rawls, The Law of Peoples (Harvard University Press, \\ 2001); Joseph Raz, 'Human Rights without Foundations', 2007; Thomas W. Pogge, \\ World Poverty and Human Rights (Polity, 2008); Charles R. Beitz, The Idea of Human \\ Rights (OUP Oxford, 2009). \\ 2. I borrow the term Political Constitutionalism from Richard Bellamy who contrasts it \\ with a model of Legal Constitutionalism that supports judicial review of rights by constitutional \\ courts. The two main works I focus on here are Richard Bellamy, Political \\ Constitutionalism: A Republican Defence of the Constitutionality of Democracy \\ (Cambridge: Cambridge University Press, 2007) and Jeremy Waldron, Law and \\ Disagreement (Oxford: Clarendon Press, 1999). Although Waldron himself does not \\ use the term, it is accepted by political constitutionalists and their critics that his \\ work makes an important normative contribution to this literature. See e.g. Richard \\ Bellamy, 'Political Constitutionalism and the Human Rights Act', International Journal \\ of Constitutional Law 9, no. 1 (2011): 5; Marco Goldoni, 'Two Internal Critiques of \\ Political Constitutionalism', International Journal of Constitutional Law 10, no. 4 \\ (October 1, 2012): 926. \\ 3. Bellamy, (n. 2, 2007), p. 20; Waldron, (n. 2), p. 102. \\ 4. There is an extensive literature by sociologists and social historians that records and \\ analyses these processes of popular claim-making. See Sidney G. Tarrow, Power in \\ Movement: Social Movements and Contentious Politics (Cambridge University Press, \\ 2011); Charles Tilly, Social Movements, 1768-2012. (Paradigm Publishers, 2012); \\ Frances Fox Piven and Richard Cloward, Poor People's Movements: Why They \\ Succeed, How They Fail (New York: Vintage, 1978); E. P. Thompson, The Making of \\ the English Working Class (New York: Vintage, 1966); CLR James, The Black Jacobins: \\ Toussaint L'Ouverture and the San Domingo Revolution (Penguin UK, 2001). \\ 5. A helpful discussion is provided in Archon Fung, 'Deliberation before the Revolution \\ Toward an Ethics of Deliberative Democracy in an Unjust World', Political Theory 33,
}

no. 3 (2005): 397-419. See also John Medearis, 'Social Movements and Deliberative Democratic Theory', British Journal of Political Science 35, no. 1 (2005): 53-75; Jean L. Cohen and Andrew Arato, Civil Society and Political Theory (Mit Press, 1994); Marc Stears, Demanding Democracy: American Radicals in Search of a New Politics (Princeton University Press, 2013).

6. Richard Bellamy, 'Rights as Democracy', Critical Review of International Social and Political Philosophy 15, no. 4 (2012).

7. Ibid., p. 451.

8. Ibid., p. 464

9. Ibid., p. 460. 
10. Ibid., p. 452.

11. Most famously Edmund Burke, Reflections on the Revolution in France (Digireads.com, 2005); and K. Marx, 'On the Jewish Question'. In D. McLellan (Ed.) Karl

Marx-Selected Writings. Second ed. (Oxford: Oxford University Press, 2000).

12. Mary Ann Glendon, Rights Talk: The Impoverishment of Political Discourse (Simon and Schuster, 2008).

13. Bellamy (n. 6), p. 459.

14. 'Introduction' in Waldron (ed.) Theories of Rights (Oxford: Oxford University Press, 1984).

15. The Morality of Freedom (Clarendon Press, 1986), p. 184.

16. Nigel E. Simmonds, 'Rights at the Cutting Edge', A Debate over Rights, Ed. Matthew

Kramer, Nigel Simmonds and Hillel Steiner, 1998, 113-232.

17. Waldron (n. 2) p. 228

18. 'The Nature and Value of Rights', The Journal of Value Inquiry 4, no. 4 (1970): 243-60. An important exception is Richard E. Flathman whose work offers important insights into the adversarial dimension of rights as a 'social practice'. The Practice of Rights (Cambridge University Press, 1976).

19. J. L Austin, How to Do Things with Words (London: Oxford Univ. Press, 1976).

20. 'Voluntary Euthanasia and the Inalienable Right to Life', Philosophy \& Public Affairs 7, no. 2 (1978): 242.

21. Wesley Newcomb Hohfeld, 'Fundamental Legal Conceptions: As Applied in Judicial Reasoning, Ed', WW Cook, New Haven, 1919, p. 36.

22. The duties that correspond to claim-rights are sometimes termed 'directed' duties in contrast to 'non-directed' duties (such as those of charity) that are owed to no specific individual. See Gopal Sreenivasan, 'Duties and Their Direction', Ethics 120, no. 3 (2010): 465-94.

23. Joel Feinberg, 'The Rights of Animals and Unborn Generations', Ethical Issues: Perspectives for Canadians, 2009, 1.

24. Feinberg (n. 18).

25. Social Philosophy, vol. 92 (Englewood Cliffs, NJ: Prentice-Hall, 1973), p. 58.

26. Stephen L. Darwall analyses the distinctive nature of interpersonal moral norms in terms of 'second personal reasons', The Second-Person Standpoint: Morality, Respect, and Accountability (Harvard University Press, 2006).

27. John Gaventa notes in his study of an Appalachian mining community that the powerless must first 'develop their own notions of interests and actions, and themselves as actors'. Power and Powerlessness: Quiescence and Rebellion in an Appalachian Valley (University of Illinois Press, 1982), 257. Mary Wollstonecraft's emphasis on the empowering effects of female education in overcoming 'blind obedience' suggests a similar understanding, A Vindication of the Rights of Woman (JPM Ediciones, 2009), 31.

28. Bellamy, (n. 2, 2011), p. 91.

29. I owe this point to Flathman (n. 18), p. 72.

30. Robert A. Williams Jr, 'Taking Rights Aggressively: The Perils and Promise of Critical Legal Theory for Peoples of Color', Law and Inequality 5 (1987): 124.

31 . The role and identity of third parties is rarely addressed explicitly in more abstract discussions of rights, although some helpful discussion is contained in Carl Wellman, The Moral Dimensions of Human Rights (Oxford University Press, 2010), pp. 34-35; Flathman (n. 18), pp. 94-95.

32. Social movement scholars term these 'repertoires of contention', see Donatella Della Porta, 'Repertoires of Contention', in The Wiley-Blackwell Encyclopedia of Social and Political Movements (Blackwell Publishing Ltd, 2013).

33. Gay marriage appears to be one right in the latter stages of this process. For a historical overview of this struggle, see Ken Plummer, 'Rights Work: Constructing Lesbian, Gay and Sexual Rights in Late Modern Times', 2006.

34. Karl Marx, Capital: A Critique of Political Economy (Penguin Books Limited, 1976), 344. Marx's views on rights are more nuanced and less critical than some of his more polemical remarks imply. See David Leopold, The Young Karl Marx: German Philosophy, Modern Politics, and Human Flourishing, 1st edition (Cambridge: Cambridge University Press, 2007), chap. 3.

35. Bellamy, (n. 2, 2007); Waldron (n. 2).

36. Bellamy, (n. 2, 2007), pp. 34-35; Waldron, (n. 2), p. 288.

37. Ran Hirschl, Towards Juristocracy (Cambridge, MA; London: Harvard University Press, 2007).

38. I refer here to the three-part typology of power, as set out in in Steven Luke's classic study, Power: A Radical View, Hampshire and New York, Palgrave Macmillan, 2005. I go on to provide empirical support for the relevance of this understanding of power to contemporary democracies. 
39. See for example, Wendy Brown, “"The Most We Can Hope For. . '”: Human Rights and the Politics of Fatalism', The South Atlantic Quarterly 103, no. 2 (2004): 451-63; and Costas Douzinas, The End of Human Rights: Critical Legal Thought at the Turn of the Century (Hart Pub, 2000). The recent critical literature on rights draws heavily on the analyses of ideology and power in Marx and Foucault. See Marx (n. 11); Michel Foucault, 'The Subject and Power', Critical Inquiry, 1982, 777-95.

40. Peter Bachrach and Morton S. Baratz, 'Two Faces of Power', American Political Science Review 56, no. 04 (1962): 947-52.

41. Bellamy (n. 2, 2007), pp. 209-59.

42. Bellamy (n. 6, 2007), pp. 463-64.

43. 'Rethinking Who Governs? New Haven, Revisited', Community Power. Directions for Future Research. (Beverly Hills: SAGE), 1986.

44. Oligarchy (Cambridge University Press, 2011), 214, 273. The most systematic empirical studies of 'oligarchy' relate to the US, see also Martin Gilens and Benjamin I. Page,

'Testing Theories of American Politics: Elites, Interest Groups, and Average Citizens', Perspectives on Politics. In Press, 2014.

45. See Colin Crouch, The Strange Non-Death of Neo-Liberalism (Cambridge, UK; Malden, MA: Polity Press, 2011); David Beetham, 'Unelected Oligarchy: Corporate and Financial Dominance in Britain's Democracy', Democracy Audit, 2011; Stephen Wilks, The Political Power of the Business Corporation (Edward Elgar Publishing, 2013). 46. Bellamy (n. 2), pp. 21-22.

47. Waldron (n. 2), p. 153.

48. The Liberal/Democratic Divide. On Rawl's Political Liberalism, 1996, 107.

49. Mathew Humphrey and Marc Stears describe this as a challenge to the 'stickiness' of 'certain cognitive frames', 'Animal Rights Protest and the Challenge to Deliberative Democracy', Economy and Society 35, no. 3 (2006): 400-22, pp. 416-17. See also Lynn M. Sanders, 'Against Deliberation', Political Theory, 1997, 347-76.

50. Medearis (n. 5), pp. 54-55.

51. Waldron (n. 2), p. 15.

52. Waldron (n. 2), pp. 101-2.

53. This is most conspicuous in Waldron's recent methodological proposals for a more 'political' mode of theorising, 'Political Political Theory: An Inaugural Lecture', Journal of Political Philosophy, 2013.

54. Bellamy (n. 2, 2007), pp. 138-9.

55. The importance of this 'expressive' dimension to social movements is discussed in Jean L. Cohen and Andrew Arato, Civil Society and Political Theory (Mit Press, 1994).

56. While I go onto highlight this difficulty with respect to the homeless and housing, Marco Goldoni identifies a parallel problem for Bellamy's theory with respect to prisoner voting rights. (2013) 'Constitutional reasoning according to political constitutionalism'. German Law Journal, 14(8): 1053-76.

57. Bellamy (n. 2, 2007), p. 139.

58. The most influential philosophical critique of socio-economic rights is Maurice Cranston, 'What Are Human Rights?', 1973. For a discussion of how free market ideology shapes public discourse on housing, see Iris Marion Young, Responsibility for Justice, Reprint edition (USA: Oxford University Press, 2010), Ch. 1.

59. See Henry Shue, Basic Rights: Subsistence, Affluence, and US Foreign Policy (Princeton University Press, 1996); Jack Donnelly, Universal Human Rights in Theory and Practice (Cornell University Press, 2003); Pogge (n. 1).

60. See Squatting Europe Kollective, 2012, Squatting in Europe: Radical Spaces, Urban Struggles, 2012; Max Rameau, Take Back the Land: Land, Gentrification and the Umoja Village Shantytown (Nia Press, 2008). The idea of a right to inhabit housing and land held by wealthy property owners has deep roots in countries worldwide, reflecting stubborn traditional beliefs about common ownership of the land and access to shelter and subsistence, see Colin Ward, Cotters and Squatters: Housing's Hidden History (Nottingham, England: Five Leaves, 2002).

61. Rameau (n. 60).

62. Max Rameau (2008), Take Back the Land: Miami Grassroots Group Moves Struggling Families into Vacant Homes. Available at: http://www.democracynow.org/2008/12/19/ take back the land miami grassroots. Last accessed 10 March 2014.

63. Waldron (n. 2), pp. 289-91; Bellamy (n. 2, 2007), pp. 48-51.

64. Ward, (n. 60).

65. Rameau, (n. 60), p. 29.

66. Michael Walzer has even suggested that the disruptive political power wielded by 'insurrections'

forms part of an 'informal bargaining process', enjoying widespread acceptance

within democracies for its capacity to keep inequalities in check, 'Should We Reclaim 
Political Utopianism?', European Journal of Political Theory, 2012, p. 29.

67. Stuart White, 'Making Anarchism Respectable? The Social Philosophy of Colin Ward', Journal of Political Ideologies 12, no. 1 (2007): 11-28.

68. See John Rawls, A Theory of Justice (Belknap Press, 1999), Ch. 6. Ronald Dworkin's

theory allows more space for creative claim-making, but is structurally similar, 'Civil disobedience and nuclear protest' in, A Matter of Principle (Oxford University Press,

1985).

69. Kesia Reeve, 'Squatting Since 1945: The Enduring Relevance of Material Need', 2005.

70. Lynn M. Harter et al., 'The Structuring of Invisibility Among the Hidden Homeless:

The Politics of Space, Stigma, and Identity Construction', Journal of Applied

Communication Research 33, no. 4 (2005): 305-27.

71. Iris Marion Young (n. 58), Ch. 1.

72. Lynn M. Harter et al (n. 70).

73. A useful discussion can be found in Fung (n. 5).

74. Rameau (n. 60).

75. The 'surface' issue of housing cannot help but raise these 'root' issues, as Rameau puts it

(n. 60), pp. 68-69. The term 'shock tactics' comes from Stears and Humphrey (n. 49).

76. Jenny Pickerill and John Krinsky, 'Why Does Occupy Matter?', Social Movement

Studies 11, no. 3-4 (2012): 279-87 